Удк 343.412

DOI https://doi.org/10.32837/apdp.v0i92.3270

Ю. B. Cподарик

\title{
ОСОБЛИВОСТІ КВАЛІФІКАЦІЇ КРИМІНАЛЬНИХ ПРАВОПОРУШЕНЬ ПРОТИ ЖУРНАЛІСТСЬКОЇ ДІЯЛЬНОСТІ
}

Постановка проблеми. Події 2013-2014 років та загалом неналежне забезпечення свободи слова в Україні останніми роками зумовили необхідність посилення кримінальної відповідальності за порушення прав журналістів. Так, 14 травня 2015 року Верховна Рада України прийняла Закон України «Про внесення змін до деяких законодавчих актів України щодо посилення гарантій законної професійної діяльності журналістів». Останнім доповнено кримінальний закон ст. 345-1 КК України - погроза або насильство щодо журналіста, ст. 347-1 КК України умисне знищення або пошкодження майна журналіста, ст. 348-1 КК України - посягання на життя журналіста, ст. 349-1 КК України - захоплення журналіста як заручника. Окрім цього, ст. 375 КК України «Постановлення суддею (суддями) завідомо неправосудного вироку, рішення, ухвали або постанови" доповнено кваліфікуючою ознакою «з метою перешкоджання законній професійній діяльності журналіста», а ст. 163 КК України «Порушення таємниці листування, телефонних розмов, телеграфної чи іншої кореспонденції, що передаються засобами зв'язку або через комп’ютер» доповнено кваліфікуючою ознакою «вчинення кримінально-протиправного посягання стосовно журналіста». Однак поява спеціальних норм щодо посилення захисту життя, здоров'я та власності журналістів за наявності загальної норми про перешкоджання законній професійній діяльності журналістів призвела до певних проблем у кваліфікації, які з огляду на відсутність у положеннях КК України правил кваліфікації повинні бути вирішені принаймні на теоретичному рівні.

Аналіз останніх досліджень і публікацій. Проблемам кримінально-правового захисту журналістів присвятили свої праці такі вчені, як П.С. Берзін, Р.В. Вереша, О.І. Готін, І.О Зінченко, О.В. Красильнікова, С.Я. Лихова, В.І. Павликівський, Є.О. Письменський та ін.

Метою статті $\epsilon$ визначення сучасних проблем кваліфікації правопорушень, що посягають на діяльність журналістів, а також встановлення можливих варіантів їх вирішення.

Виклад основних положень. Натепер найбільш відоме визначення кваліфікації кримінального правопорушення належить В.М. Кудрявцеву, який визначає iї як встановлення і юридичне закріплення точної відповідності між ознаками вчиненого діяння і ознаками складу кримінального правопорушення, передбаченого кримінально-правовою нормою [1, с. 7-8]. Кваліфікація кримінальних правопорушень є підставою для призначення покарання, звільнення від кримінальної відповідальності і від покарання, застосування примусових заходів виховного характеру до неповнолітніх та частково й опосередковано застосування примусових заходів медичного характеру. Це дозволяє констатувати, що кваліфікація

(C) Ю. В. Сподарик, 2021 
кримінальних правопорушень є основоположною, фундаментальною, центральною, стрижневою частиною, ядром застосування кримінального закону у слідчій та судовій практиці [2, с. 10]. У кваліфікації кримінального правопорушення знаходить вияв принцип персональної відповідальності особи за конкретне діяння, передбачене законом. Звідси випливає, що лише правильна кваліфікація є однією з гарантій здійснення правосуддя відповідно до закону [1, с. 28].

Правильно кваліфікувати кримінальне правопорушення означає застосувати той закон, який точно відповідає вчиненому, дає правильну оцінку діям злочинця, відображає інтереси суспільства та захищає права і свободи особи. Помилка в кваліфікації може потягнути за собою не тільки неправильне призначення покарання, а й викликати у суспільства відчуття безкарності або, навпаки, жорстокості законодавця.

Як правильно зазначає В.Н. Кудрявцев, «весь процес кваліфікації складається з послідовного відмежування кожної ознаки вчиненого діяння від ознак інших, суміжних злочинів» [1, с. 126]. Кожне кримінальне правопорушення має низку загальних ознак з іншими. Проблеми у разі кваліфікації викликаються саме цією обставиною. Для того щоб правильно кваліфікувати кримінальне правопорушення, необхідно досить чітко уявляти розмежувальні лінії між ним і суміжними кримінальними правопорушеннями. Установлюючи властиві певному діянню ознаки, виключаючи ті ознаки, які йому не притаманні, поступово поглиблюючи аналіз правової норми, можна дійти до тієї сукупності ознак, які характеризують саме це діяння, відрізняючи його від інших [1, с. 126].

Для здійснення правильної кваліфікації кримінальних правопорушень, передбачених ст. ст. 171, 345-1, 347-1, 348-1, 349-1, ч. 2 ст. 163, ч. 2 ст. 375 КК України, що посягають на професійну діяльність журналістів, обов'язковим $є$, по-перше, встановлення факту, що потерпілим виступає саме журналіст, а відповідно до статті 1 Закону України «Про державну підтримку засобів масової інформації та соціальний захист журналістів» від 23.09.1997 р. № 540/97-ВР журналіст це творчий працівник, який професійно збирає, одержує, створює та займається підготовкою інформації для засобів масової інформації, виконує редакційно-посадові службові обов'язки у засобі масової інформації (в штаті або на позаштатних засадах) відповідно до професійних назв посад (роботи) журналіста, які зазначаються в державному класифікаторі професій України [3]. По-друге, необхідно, щоб діяльність журналіста була законною, тобто діяльність журналістів повинна бути спрямована на реалізацію ними своїх повноважень у інформаційній сфері і здійснюватися засобами та в порядку, що передбачені законом, в іншому випадку зазначена кваліфікація за вказаними складами виключається. По-третє, слід розмежовувати такі, здавалося б, тотожні категорії, як «діяльність журналіста (професійна діяльність)» і «журналістська діяльність». Виходячи з кримінально-правового розуміння категорії «професійна діяльність» як об'єкта кримінально-правової охорони, можна дійти висновку, що якщо особа, не маючи юридично оформленого зв'язку із засобом масової інформації, інформаційним агентством або іншим суб'єктом інформаційної діяльності, що діє з метою надання інформаційних послуг, за власною ініціативою займалася журналістською діяльністю і щодо неї мало місце вчинення кримінального правопорушення у зв’язку з цією діяльністю, 
то притягнення винного до кримінальної відповідальності за цими статтями (тобто, в яких одним із безпосередніх об'єктів виступає законна професійна діяльність журналістів) є порушенням правил кримінально-правової кваліфікації, оскільки жодної мови про виконання цією особою професійної діяльності журналіста бути не може [6, с. 45-46].

Як зазначалось вище, після внесення відповідних змін професійна діяльність журналістів в Україні почала охоронятись не однією 171 статтею КК України, а ще чотирма спеціальними, а саме 345-1, 347-1, 348-1, 349-1 КК України. Сама стаття 171 також зазнала змін. Так, у ч. 1 ст. 171 КК України законодавець встановив відповідальність за незаконне вилучення зібраних, опрацьованих, підготовлених журналістом матеріалів і технічних засобів, якими він користується у зв’язку зі своєю професійною діяльністю, незаконну відмову у доступі журналіста до інформації, незаконну заборону висвітлення окремих тем, показу окремих осіб, критики суб'єкта владних повноважень, а так само будь-яке інше умисне перешкоджання здійсненню журналістом законної професійної діяльності, а у ч. 2 ст. 171 КК України - за вплив у будь-якій формі на журналіста з метою перешкоджання виконанню ним професійних обов'язків або переслідування журналіста у зв'язку з його законною професійною діяльністю. У ч. 3 ст. 171 КК України законодавець передбачив кваліфікуючу норму стосовно ч. 2 ст. 171 КК України, у якій йдеться про дії, передбачені частиною другою цієї статті, якщо вони були вчинені службовою особою з використанням свого службового становища або за попередньою змовою групою осіб. Отже, законодавець у ст. 171 КК України незаконний вплив на журналіста розділив залежно від спрямованості умислу та мети кримінально-протиправної діяльності.

У першій частині йдеться про спрямованість кримінально-протиправних дій на запобігання, зміну або припинення законних дій журналіста, наприклад, обмеження доступу до інформації з метою перешкоджання виходу викривальної публікації. У другій частині кримінально-протиправними визнаються дії, що виступають як помста за вже виконану журналістську діяльність, зокрема публікацію певного матеріалу. Способи незаконного впливу лежать за межами цього складу кримінального правопорушення й можуть бути різними - від умовляння, підкупу, залякування до вбивства журналіста. Аналіз судової практики дає змогу стверджувати, що здебільшого перешкоджання журналістській діяльності здійснюється шляхом пошкодження або відбирання апаратури, у меншій кількості - шляхом застосування погроз або насильства. Із наявних у Єдиному державному реєстрі судових рішень на 01.02.2020 р. 27 вироків за ст. 171 КК України 12 пов'язані із завданням тілесних ушкоджень журналістам [4].

До появи розглядуваних змін дії винних осіб у разі перешкоджання законній журналістській діяльності способом, що є самостійним кримінальним правопорушенням, кваліфікувалися за сукупністю кримінальних правопорушень. Наприклад, завдання легких тілесних ушкоджень з метою перешкоджання виконанню журналістом своїх обов'язків кваліфікувалось за ч. 1 ст. 171 і ст. 125 КК України [5]. Із прийняттям Закону України «Про внесення змін до деяких законодавчих актів України щодо посилення гарантій законної професійної діяльності журналістів» 
виникають закономірні питання щодо можливості і правильності цієї кваліфікації. Ст. ст. 345-1, 347-1, 348-1, 349-1 КК України передбачають відповідальність за різні форми незаконного впливу на журналіста у зв'язку зі здійсненням журналістом законної професійної діяльності. Законодавець наголошує на обов'язковій наявності зв’язку між кримінально-протиправними діями та журналістською діяльністю потерпілого, тому за вказаними статтями відповідальність настає як за дії, що здійснюються з метою запобігання або припинення журналістської діяльності, так і ті дії, що є помстою (переслідуванням) за вже виконані дії. Водночас визначення спрямованості й цілі кримінально-протиправних дій є обов’язковим для правильної кваліфікації за відповідною частиною ст. 171 КК України. Якщо насильство або погроза застосування насильства здійснюється з метою перешкоджання законній професійній діяльності журналіста, дії винного потрібно кваліфікувати за сукупністю кримінальних правопорушень, передбачених ст. ст. 345-1, 347-1, 348-1, 349-1 КК України (залежно від характеру насильства) та ч. 1 ст. 171 КК України. У разі ж переслідування за вже виконану професійну діяльність дії винного потрібно кваліфікувати за сукупністю кримінальних правопорушень, передбачених відповідно ст. ст. 345-1, 347-1, 348-1, 349-1 КК України (залежно від характеру насильства) та ч. 2 ст. 171 КК України. Не варто забувати і про можливу кваліфікацію за ч. 3 ст. 171 КК України, яка матиме місце лише у разі скоєння кримінального правопорушення службовою особою або за попередньою змовою групою осіб. В інших ситуаціях дії винної особи кваліфікуються лише за ст. ст. 345-1, 347-1, 348-1, 349-1 КК України [7, с. 111]. Таким чином, наявність додаткових спеціальних норм у кримінальному законі лише зумовила складніший процес кримінально-правової кваліфікації та його кількісне наповнення, що аж ніяк не свідчить про ефективні зміни у механізмі кримінально-правового захисту журналістів.

Щоб переконатись у штучно створеному ускладненому процесі кваліфікації, пропонується розглянути найбільш імовірні випадки поєднання кримінальних правопорушень проти журналістів із суміжними кримінальними правопорушеннями.

Так, до прикладу, ч. 1 ст. 345-1 КК України передбачає відповідальність за погрозу вбивством, насильством або знищенням чи пошкодженням майна журналіста, а також щодо його близьких родичів чи членів сім'ї у зв’ язку зі здійсненням ним законної професійної діяльності. При цьому у КК України існує ще декілька правових норм, що передбачають відповідальність за такі кримінальні правопорушення, як «Погроза вбивством» (ст. 129 КК України), «Погроза або насильство щодо працівника правоохоронного органу» (ст. 345 КК України), «Погроза або насильство щодо судді, народного засідателя чи присяжного» (ст. 377 КК України), «Погроза або насильство щодо захисника чи представника особи» (ст. 398 КК України). Тому постає цілком слушне питання про відмежування та співвідношення цих норм. У випадку зі ст. 345-1 КК України діяння містить ознаки як мінімум двох кримінально-правових норм. Але це положення свідчить про наявність не сукупності злочинів, а конкуренції кримінально-правових норм, i, на відміну від сукупності, у разі конкуренції норм вчиняється один злочин, хоча він і містить ознаки двох (або більше) кримінально-правових норм [8, с. 177]. Зокрема, вона вбачається перш за все у разі зіставлення двох правових норм, що 
передбачають відповідальність за погрозу вбивством ст. 129 КК України і погрозою або насильством щодо журналіста ст. 345-1 КК України. Йдеться про такий вид конкуренції кримінальних норм, як конкуренція загальної та спеціальної норм, вона виникає у зв'язку із прагненням законодавця диференціювати кримінальну відповідальність шляхом виділення із загальної норми спеціальних норм, які передбачають або більш сувору або, навпаки, більш м'яку відповідальність порівняно із загальною нормою. У теорії кримінального права застосовується правило, згідно з яким у разі конкуренції загальної та спеціальної норм дії винного повинні кваліфікуватися за спеціальною нормою, незалежно від того, яка міра покарання передбачена в її санкції: більш м'яка чи, навпаки, більш тяжка. Стаття 129 КК України є загальною нормою, а ст. 345-1 КК України - спеціальна норма стосовно погрози вбивством, тобто за такого виду конкуренції завжди застосовується спеціальна норма. Тому кваліфікувати дії винного в цьому разі слід тільки за ст. 345-1 КК України, і додаткова кваліфікація за ст. 129 КК України за погрозу вбивством не потрібна.

Аналогічно вирішується питання з кримінально-правовою нормою, передбаченою ст. 195 КК України «Погроза знищення майна», ст. 125 КК України «Умисне легке тілесне ушкодження», ст. 122 КК України «Умисне середньої тяжкості тілесне ушкодження», ст. 121 КК України «Умисне тяжке тілесне ушкодження», які є загальними для ч. 2, 3 ст. 345-1 КК України. Кримінальними правопорушеннями одного ряду з досліджуваною нормою є склади кримінальних правопорушень, передбачених ст. 345, 377, 398 КК України. Від кримінальних правопорушень, передбачених ст. 345-1 КК України, вони відрізняються насамперед безпосереднім об'єктом злочинного посягання. Відмежовують зазначені кримінальні правопорушення і за різного роду потерпілими. Мотиви вчинення зазначених кримінальних правопорушень є тотожними - бажання припинити певні дії потерпілого або помста за його правомірну діяльність [8, с. 178].

Доцільно зазначити, що склади кримінального правопорушення ч. 1,2 та 3 ст. 345-1 КК України є відсильними до інших статей КК України (ст. 121, 122, 125, $345,377,398)$. Оскільки закріплені в них суспільно небезпечні діяння знаходять свою самостійну кримінально-правову оцінку в них. Кримінально-правові норми, що містяться в останніх, знаходяться у співвідношенні з нормами ст. 345-1 КК України як загальні зі спеціальними. Підставою їх розмежування є мета вчинення кримінального правопорушення, яка у разі вчинення погрози або насильства щодо журналіста виступає обов'язковою ознакою суб'єктивної сторони та виражає бажання винного вплинути на законну професійну діяльність журналіста з метою перешкоджання їй. За умови існування іншої мети - дії винного слід кваліфікувати як кримінальне правопорушення проти життя та здоров'я особи. Тобто сформований у межах ст. 345-1 КК України об'єкт кримінально-правової охорони охоплює виключно ті суспільні відносини, що реалізуються як законна журналістська діяльність.

Складнощі у разі кваліфікації виникають під час відмежування ст. 347-1, якою передбачено умисне знищення або пошкодження майна журналіста від інших суміжних кримінальних правопорушень. Так, до прикладу, стаття 194 КК України встановлюе відповідальність за умисне знищення або пошкодження майна 
і тим самим є загальною стосовно 347-1 КК України. Основна відмінність між ними полягає у потерпілому, позаяк за ст. 194 КК України потерпілим може бути власник або володілець майна, а за ст. 347-1 КК України ним може виступати лише журналіст або близькі родичі чи члени сім'ї журналіста. Ще одна відмінність полягає у тому, що за ч. 1 ст. 194 КК України відповідальність настає у разі заподіяння шкоди у великих розмірах, а за ч. 2 ст. 194 КК України за шкоду в особливо великих розмірах, у ст. 347-1 КК України розмір шкоди значення не має. Однак варто зазначити, що в Особливій частині КК України є ще низка складів кримінальних правопорушень, які передбачають відповідальність за умисне знищення чи пошкодження майна незалежно від розміру заподіяної шкоди. Зокрема, йдеться про «Умисне знищення або пошкодження майна службової особи чи громадянина, який виконує громадський обов’язок» (ст. 352 КК України), «Умисне знищення або пошкодження майна судді, народного засідателя чи присяжного» (ст. 378 КК України), «Умисне знищення або пошкодження майна захисника чи представника особи» (ст. 399 КК України), «Умисне знищення або пошкодження військового майна» (ст. 411 КК України) [10]. Однак видається, що для уникнення проблем у разі кваліфікації і загалом для спрощення цього процесу варто було б законодавчо чітко визначити, який розмір шкоди потрібно визначити як ознаку простого складу кримінального правопорушення (ч. 1 ст. 347 КК України), а який мав би бути шкодою, котра б вважалася «значною шкодою» і виконувала б роль кваліфікуючої ознаки цього кримінального правопорушення. Адже якщо діянням не заподіяно істотної шкоди фізичній особі у цьому разі журналісту чи його близьким родичам, то має місце малозначність діяння, а як відомо, якщо в діянні встановлені ознаки малозначності діяння, справа підлягає закриттю за відсутністю складу злочину [9]. Або простіший варіант - залишити лише ст. 194 КК України, а ст. 347-1 КК України виключити з кримінального закону.

Чимало труднощів у разі кваліфікації виникає також під час застосування ст. 348-1 КК України, яка передбачає відповідальність за посягання на життя журналіста. Під посяганням на життя журналіста у цій статті належить розуміти вбивство або замах на вбивство журналіста, його близьких родичів чи членів сім'ї у зв'язку зі здійсненням цим журналістом законної професійної діяльності [2]. Встановлення кримінальної відповідальності за таке діяння взагалі не є обгрунтованим, адже існує п. 8 ч. 2 ст. 115 Кримінального кодексу України, яким передбачено умисне вбивство особи чи ї̈ близького родича у зв'язку з виконанням цією особою службового або громадського обов'язку [10]. Більше того, санкція статті 348-1 Кримінального кодексу України є менш суворою, ніж санкція п. 8 ч. 2 ст. 115 Кримінального кодексу України, зважаючи на її нижню межу, а в такому разі виникають сумніви в необхідності прийняття окремої норми про відповідальність за посягання на життя журналіста. Ще одним проблемним моментом у разі кваліфікації за статтею 348-1 Кримінального кодексу України є те, що ані в назві статті, ні в тексті диспозиції не вказується на форму вини злочинного діяння. I хоча системне тлумачення норми дозволяє дійти висновку про наявність лише умисної форми вини, це не виключає виникнення певних розходжень у процесі застосування зазначеної кримінально-правової норми. Не може не викликати суттєвих зауважень 
факт поєднання в межах однієї статті двох самостійних стадій вчинення злочинного діяння: замаху та закінченого злочину. Бажання законодавця підсилити значення вказаної кримінально-правової норми призвело до порушень системності кримінального законодавства та нівелювання значення Загальної частини Кримінального кодексу України. Стаття 16 Кримінального кодексу України визначає, що відповідальність за замах на злочин настає за тією ж статтею Особливої частини Кримінального кодексу, яка передбачає відповідальність за закінчений злочин. До того ж абзац 2 п. 6-1 ППВСУ вказує, що положення частин 2 і 3 ст. 68 (призначення покарання за готування і замах) не можуть бути застосовані у разі призначення покарання особі, яка віком 18 і більше років вчинила злочин, за який передбачено найбільш суворий вид покарання - довічне позбавлення волі, оскільки цей вид покарання є таким, що виключає можливість призначення його половини чи двох третин [3]. Таким чином, суд, призначаючи покарання за замах на вбивство журналіста, повинен керуватися положеннями лише санкції статті, без врахування вимог ст. 68 Кримінального кодексу України, що практично нівелює необхідність виділення замаху як окремої форми злочинного діяння. 3 огляду на це можна зробити висновок, що наявність ст. 348-1 КК України створює чимало проблем, а тому найправильнішим кроком було б виключити її із кримінального закону.

У разі кваліфікації за ст. 349-1 КК України, якою передбачене захоплення журналіста як заручника, варто звернути увагу на суміжне кримінальне правопорушення, передбачене ст. 147 КК України, що містить покарання за захоплення заручників. Основною відмінністю між цими кримінальними правопорушеннями є потерпілий та спеціальна мета. Адже за ст. 349-1 КК України, на відміну від ст. 147 КК України, потерпілим може виступати лише журналіст або його близькі родичі чи члени сім'ї, а спеціальною метою є спонукання до дії або відмову від неї лише одного адресата - саме цього журналіста. Крім того, термін «будь-які дії» у ст. 349-1 КК України обмежує коло таких дій лише професійною журналістською діяльністю потерпілого. У разі конкуренції загальної та спеціальної норми перевага буде на стороні спеціальної, як і у всіх попередніх випадках, однак наявність по суті «зайвого» складу лише породжує непотрібну у такому разі конкуренцію норм. У разі необхідності посилення відповідальності за захоплення як заручника певної категорії осіб законодавцю досить сконструювати кваліфікований склад злочину до вже наявної статті 147 КК України, з огляду на це можна зробити висновок про необхідність виключення спеціальної статті 349-1 КК України із Кримінального кодексу України.

Окрім запровадження спеціальних норм, Кримінальний кодекс України було доповнено кваліфікуючими ознаками у ст. ст. 163 (ч. 2) та 375 (ч. 2). Так, ст. 163 ККУкраїни «Порушення таємницілистування, телефоннихрозмов, телеграфної чи іншої кореспонденції, що передаються засобами зв'язку або через комп'ютер» доповнено такою кваліфікуючою ознакою, як вчинення кримінально-протиправного посягання стосовно журналіста. А частина 2 ст. 375 КК України з останніми змінами передбачає відповідальність за постановлення суддею (суддями) завідомо неправосудного вироку, рішення, ухвали або постанови з метою перешкоджання законній професійній діяльності журналіста. Варто зауважити недоцільність впровадження до ч. 2 ст. 163 КК України такої кваліфікуючої ознаки, як вчинення 
кримінально-протиправного посягання стосовно журналіста, оскільки предметом такого кримінального правопорушення є приватні відомості, що передані чи передаються громадянами через листування або телефонні розмови й ін., а незаконне ознайомлення зі службовою кореспонденцією, телефонними розмовами, телеграфними та іншими повідомленнями журналіста та їх розголошення за наявності для того підстав повинні кваліфікуватися як перешкоджання професійній діяльності журналіста за ч. 1 ст. 171 КК. Адже у такому разі відбувається необгрунтоване надання переваги одним правам над конституційними правами інших осіб [6, с. 139].

Доповнення ж до ч. 2 ст. 375 КК України викликані останніми тенденціями у сфері перешкоджання законній професійній діяльності журналістів. Буденним явищем останніх років є використання судових органів у боротьбі зі ЗМI, забороні публікацій певного змісту або примус до спростування інформації за допомогою судових рішень. У зв'язку з цим законодавчі зміни до кримінального законодавства вимагають перегляду питання співвідношення вказаного складу із перешкоджанням законній професійній діяльності журналістів. Постановлення неправосудного вироку, рішення, ухвали або постанови з метою перешкоджання законній професійній діяльності журналіста вимагає прийняття рішення слідчим щодо необхідності кваліфікації зазначених дій лише за ч. 2 ст. 375 КК України або за сукупністю кримінальних правопорушень, передбачених ч. 2 ст. 375 КК України та ч. 1 ст. 171 КК України [7, с. 111].

Для прийняття обгрунтованого рішення необхідно проаналізувати зазначені склади. Постановлення суддею неправосудного рішення є одним із можливих способів перешкоджання законній професійній діяльності журналіста. Водночас указівка на мету не охоплює собою кримінально-протиправні дії, пов'язані безпосередньо із перешкоджанням журналістській діяльності. Мета винесення неправосудного рішення лежить за межами складу ч. 2 ст. 375 КК України й не охоплюється зазначеним складом. Отже, винесення судового рішення є лише готуванням до перешкоджання законній журналістській діяльності, що має самостійне значення, а тому кваліфікація зазначених дій повинна здійснюватися за сукупністю кримінальних правопорушень, передбачених ст. ст. 375 і 171 КК України [7, с. 111]. Однак дані Єдиного державного реєстру судових рішень свідчать, що до 01.02.2021 року так і не з'явилось жодного вироку за ч. 2 ст. 375 КК України, що стосується перешкоджання діяльності журналістів [4], а це ставить під сумнів доцільність проведених змін і питання про необхідність їх залишення.

Висновки. Аналіз законодавчих нововведень показує, що вони радше викликали чимало запитань у сфері їх реалізації правоохоронними органами, вирішенні проблем сукупності та відмежування від суміжних складів кримінальних правопорушень, аніж покращили ситуацію із кримінально-правовим захистом журналістів. На практиці питання кримінально-правової кваліфікації викликають чимало труднощів, нерідко допускаються помилки в кваліфікації, а в такому разі збільшення кількості норм, що регулюють діяльність журналістів, лише невиправдано збільшило ймовірність допущення таких помилок та загалом ускладнило цей процес. 3 огляду на все вищезазначене найдоцільнішим кроком законодавця було би виключити всі спеціальні норми, що стосуються захисту журналістів із Кримінального кодексу України, а зі ст. ст. 163, 375 КК України згадку про журналістів як таку. 


\section{Jimepamypa}

1. Кудрявцев В. Н. Общая теория квалификации преступлений. Москва : Юридическая литератуpa, 1972. $352 \mathrm{c}$.

2. Гаухман Л. Д. Квалификация преступлений: закон, теория, практика. Москва : АО «Центр ЮрИнфоР», 2001. 316 с.

3. Про державну підтримку засобів масової інформації та соціальний захист журналістів : Закон України від 23.09.1997 р. № 540/97. Відомості Верховної Ради України (ВВР). 1998. № 50. Ст. 302.

4. Єдиний державний реєстр судових рішень. URL: https://reyestr.court.gov.ua/

5. Вирок № 130/52/13-к Жмеринського міськрайонного суду Вінницької області від 20.02.2013 р. URL: http://www.reyestr.court.gov.ua/Review/29447962

6. Буряк К. М. Злочини проти професійної діяльності журналістів в Україні: кримінальноправове та кримінологічне дослідження : дис. ... канд. юрид. наук : 12.00.08. Ун-т держ. фіскальної служби України. Дніпро, 2018. 245 с.

7. Павликівський В. І. Особливості кваліфікації перешкоджання законній професійній діяльності журналістів. Наук. вісн. Міжнародного гуманітарного університету. Сер. Юриспрудениія. 2015. № 15(2). C. 109-112.

8. Бондарчук А. С. Кримінально-правова характеристика погрози або насильства щодо журналіста в Україні : дис. ... канд. юрид. наук : 12.00 .08 «Кримінальне право та кримінологія; кримінально-виконавче право». Київ, 2019. 269 с.

9. Кримінальний процесуальний кодекс України. Відомості Верховної Ради Украӥни (ВВР). Київ, 2014. № 46. ст. 2046. URL: http://zakon3.rada.gov.ua/laws/show/4651-17

10. Кримінальний кодекс України від 05.04.2001 № 2341-III. URL: https://zakon.rada.gov.ua/ laws/show/2341-14

\section{Анотація}

Сподарик Ю. В. Особливості кваліфікації кримінальних правопорушень проти журналістської діяльності. - Стаття.

У статті аналізуються окремі проблемні питання кримінально-правової кваліфікації правопорушень проти журналістської діяльності. Досліджено поняття, значення та важливість правильної кваліфікації для здійснення правосуддя відповідно до закону. Розглянуто основні істотні ознаки, встановлення яких є обов'язковим для правильної кваліфікації кримінальних правопорушень, що посягають на законну професійну діяльність журналістів. Проаналізовано статтю 171 Кримінального кодексу України, якою передбачено перешкоджання законній професійній діяльності журналістів та додаткові спеціальні, зокрема ст. ст. 345-1, 347-1, 348-1, 349-1 Кримінального кодексу України, зроблено висновок про ускладнення процесу кваліфікації з появою нових статей у кримінальному законі. Зокрема, постає питання про відмежування та співвідношення, до прикладу норм, передбачених статтями 129 «Погроза вбивством» та 345-1 «Погроза або насильство щодо журналіста», 194 «Умисне знищення або пошкодження майна» та 347-1 «Умисне знищення або пошкодження майна журналіста», 115 (п. 8 ч. 2) «Умисне вбивство особи чи їі близького родича у зв'язку 3 виконанням цією особою службового або громадського обов'язку» та 348-1 «Посягання на життя журналіста», 147 «Захоплення заручників» та 349-1 «Захоплення журналіста як заручника» Кримінального кодексу України. З'ясовано, що в одних випадках підставою їх відмежування є різного роду потерпілий, в інших - мета вчинення кримінального правопорушення чи розмір заподіяної шкоди. Розглянуто ст. 163 «Порушення таємниці листування, телефонних розмов, телеграфної чи іншої кореспонденції, що передаються засобами зв'язку або через комп'ютер» та ст. 375 «Постановлення суддею (суддями) завідомо неправосудного вироку, рішення, ухвали або постанови», які було доповнено кваліфікуючими ознаками стосовно журналістів, та доведено недоцільність та неефективність проведених змін. Зроблено висновок про механічно ускладнений законодавцем процес кваліфікації, а також збільшення кількості помилок у разі кваліфікації саме через надмірну кількість норм, що регулюють журналістську діяльність.

Ключові слова: журналіст, кримінальне правопорушення, кримінальна відповідальність, кваліфікація, перешкоджання законній професійній діяльності журналістів. 


\section{Summary}

Spodaryk Yu.V.Qualification features of criminal offenses against journalistic activity. - Article.

The article analyzes some problematic issues of criminal-law qualification of offenses against journalistic activity. The concept, meaning and importance of the right qualification for the administration of justice in accordance with the law are studied. The main essential features are considered, the establishment of which is obligatory for the correct qualification of criminal offenses that encroach on the lawful professional activity of journalists. Article 171 of the Criminal Code of Ukraine, which provides obstruction of the lawful professional activity of journalists is analyzed and additional special ones, in particular Art. Art. 345-1,347-1, 348-1, 349-1 of the Criminal Code of Ukraine are analyzed too, and the conclusion is made that the qualification process became more complicated with the appearance of new articles in the Criminal Code. In particular, arises the question of delimitation and correlation, of the norms provided, for example, in Articles 129 "Threat of murder" and 345-1 "Threat or violence against a journalist", 194 "Intentional destruction or damage of the property" and 347-1 "Intentional destruction or damage of journalist property", 115 (item 8 part 2) "Intentional murder of a person or his close relative in connection with the performance of official or public duty by this person" and 348-1 "Encroachment on journalist life", 147 "Hostage-taking" and 349-1 "Taking a journalist as a hostage" of the Criminal Code of Ukraine. It was found that in some cases the reason for their separation is a different kind of victim, in others - the purpose of the criminal offense or the amount of damage. Article 163 "Violation of the secrecy of correspondence, telephone conversations, telegraph or other correspondence transmitted by means of communication or computer" and Article 375 "Ruling by the judge (judges) of a knowingly unjust sentence, decision, ruling or resolution", which were supplemented by qualifying criteria for journalists are considered and the inexpediency and ineffectiveness of these changes is proved. It is concluded that the qualification process is mechanically complicated by the legislator, as well as an increase in the number of errors in qualification due to the excessive number of norms which governs journalistic activity.

Key words: journalist, criminal offence, criminal liability, qualification, obstruction of the lawful professional activity of journalists. 